\title{
Bulgaria: Sea-Level Change and Submerged Settlements on the Black Sea
}

\author{
Preslav Peev, R. Helen Farr, Vladimir Slavchev, \\ Michael J. Grant, Jon Adams, and Geoff Bailey
}

\begin{abstract}
The Black Sea is recognised as having great potential for the preservation of submerged prehistoric sites because of the large area of land exposed on the continental shelf at lowest sea levels, especially along its western and north-western coastlines. However, very few have been discovered to date, and those that are known are located in Bulgaria. Because of the complexities associated with the periodic isolation of the Black Sea from the Mediterranean and its reconnection, offshore research has tended to focus on geological and geophysical investigation of inundation history, with unresolved and strongly held disagreements about the timing and rapidity of sea level rise at the end of the Last Glacial and
\end{abstract}

P. Peev $(\bowtie)$

Institute of Oceanology, Bulgarian Academy of

Sciences, Varna, Bulgaria

e-mail: peev@io-bas.bg

R. H. Farr

The Centre for Maritime Archaeology, University of

Southampton, Highfield, Southampton, UK

e-mail: r.h.farr@soton.ac.uk

V. Slavchev

Museum of Archaeology, Varna, Bulgaria its potential human impact. In Bulgaria, a rich concentration of underwater prehistoric sites has been discovered, thanks to dredging activities earlier in the twentieth century and a long tradition of underwater archaeological investigations going back to the 1970s. These demonstrate the presence of substantial in situ village settlements of Eneolithic and Early Bronze Age date in shallow water $(<10 \mathrm{~m})$, with excellent preservation of large ceramic assemblages, wooden structures and faunal and palynological data on palaeodiet and palaeoeconomy. More recently, large-scale marine-geological and archaeological projects have begun, aimed at integrating shallow-water inshore investigations with offshore survey in deeper water.

\section{J. Grant \\ Coastal and Offshore Archaeological Research Services (COARS), Ocean and Earth Science, National Oceanography Centre Southampton, University of Southampton, Southampton, UK e-mail:m.j.grant@soton.ac.uk}

\section{J. Adams}

The Centre for Maritime Archaeology, University of Southampton, Highfield, Southampton, UK e-mail:jjra@soton.ac.uk

\section{G. Bailey}

Department of Archaeology, University of York, York, UK

College of Humanities, Arts and Social Sciences, Flinders University, Adelaide, SA, Australia e-mail: geoff.bailey@york.ac.uk 


\section{Keywords}

Eneolithic $\cdot$ Early Bronze Age $\cdot$ Sea-level change $\cdot$ Underwater settlements $\cdot$ Flood hypothesis

\subsection{Introduction}

The Black Sea is an intercontinental enclosedtype marine basin, located between Europe and Asia, bounded by Bulgaria and Romania to the west, Ukraine to the north-west, Russia and Georgia to the north-east and east and Turkey to the south, with a surface area of $416,790 \mathrm{~km}^{2}$ and a maximum depth of $2212 \mathrm{~m}$. It is bordered by the East European Plain to the north, the Pontic Mountains of the Asia Minor Peninsula to the south, the Danubian Plain and folded morphostructures of the Balkans to the west and the Caucasus Mountain Chain with the Colchis
Lowland to the east (Fig. 20.1; Ivanov and Belokopytov 2013; Kotsev et al. 2017; YankoHombach et al. 2017; Kadurin et al., Chap. 21, this volume).

The Black Sea is a constituent part of the Greater Mediterranean Sea, connected to the Sea of Marmara in the south via the Bosphorus channel, and to the Sea of Azov by the Kerch Strait in the north. However, periodically in the Late Quaternary during periods of low global sea level, the Black Sea was isolated and formed a freshwater or brackish lake (Badertscher et al. 2011). The most recent episode of isolation was during the Last Glacial period, and the question as to when this isolation occurred, how long it persisted, the lake levels during this period and the nature of the reconnection of the lake with the global marine system through the Bosphorus, informs an intense debate about Black Sea inundation and its human impact (for details of this debate see Ryan et al. 1997, 2003; Aksu et al.

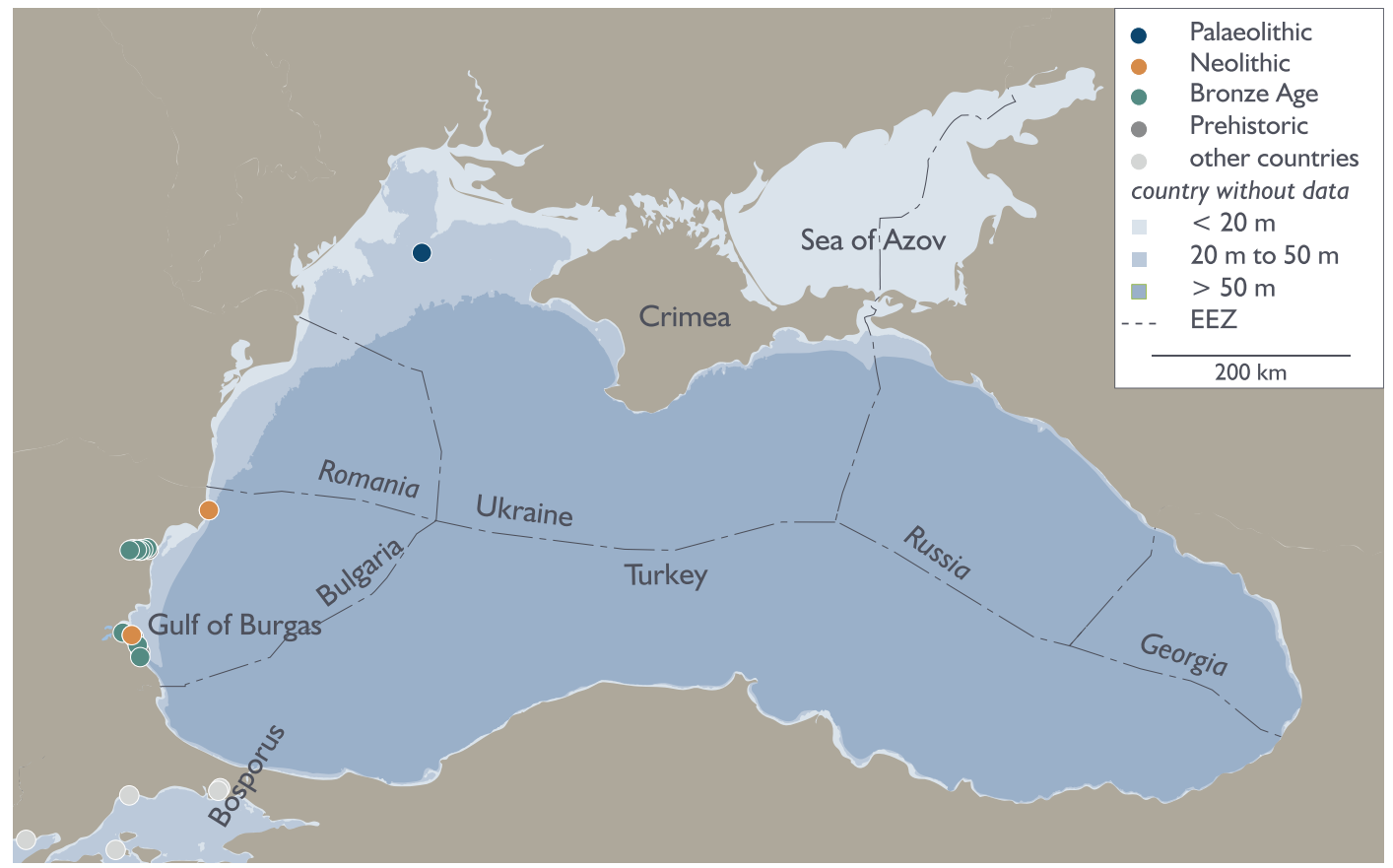

Fig. 20.1 General map of the Black Sea showing distribution of underwater sites, simplified bathymetry and the boundaries of the exclusive economic zones of each state (the boundary between Russia and the Ukraine is in dispute at the time of writing following the annexation of Crimea in 2014). The Palaeolithic site in Ukraine refers to artefacts recovered from a marine core (see Kadurin et al., Chap. 21, this volume). Site information from the SPLASHCOS Viewer http://splashcos-viewer.eu. Drawing by Moritz Mennenga 
2002; Hiscott et al. 2007; Ryan 2007; Giosan et al. 2009; Constantinescu et al. 2015; Lericolais 2017; Turney and Brown 2007; Yanko-Hombach et al. 2007a, b, 2011, 2017; Yanchilina et al. 2017; Sturt et al. 2018; Kadurin et al., Chap. 21, this volume).

In terms of its cultural significance, the Black Sea forms a meeting point between Europe and Asia. It encompasses diverse climates and environments from the Mediterranean and the Near East in the south to the Eurasian Steppe in the north. In addition, it drains some of Europe's largest rivers, notably the Danube, Dneiper, Dniester and Southern Bug, rivers that enable connectivity deep into the continent. At various times, the Black Sea has been described as a barrier, frontier or buffer between the 'civilized' and 'Barbarian' worlds (Ivanova 2013, p. 2), at other times as a medium for providing access to resources, ease of movement and avenues for cultural connectivity and trade throughout the region (Draganov 1995, p. 225). The archaeology reflects these varying potentials, with a long sequence of human presence that extends back to the Early Pleistocene at Dmanisi in Georgia at 1.85-1.78 million years ago (Mgeladze et al. 2011). Numerous Middle and Upper Palaeolithic sites are also present, especially in the north and west and in Anatolia to the south (Özdoğan 2011; Kadurin et al., this volume). In terms of later prehistoric periods, the Black Sea region has culturally diverse and complex Neolithic and Chalcolithic sites and was central to the dispersal of agriculture from the Near East and to the development of metallurgy.

Given the extent of the submerged landscapes around the Black Sea, especially in the west and the north, and the complex history of sea-level change, an investigation of their potential to preserve prehistoric sites is compelling. The coast of Bulgaria is of central importance in such an investigation. It has a relatively wide continental shelf, c. $40-50 \mathrm{~km}$ in width, which would have exposed substantial areas of habitable territory at low sea-level stands. It is close to the main pathways of cultural connection between Anatolia and Europe via the Sea of Marmara to the south and the Danube River basin to the north. Most importantly, it is the only country with a Black Sea coastline that has produced unquestionable evidence for the preservation of underwater prehistoric settlements associated with submerged palaeoshorelines (for a recent summary, see Peev and Slavchev 2018).

The aim of this chapter is to summarise the issues associated with sea-level change in the Black Sea and their impact on the palaeogeography of the Bulgarian coast and the potential for archaeological preservation, to present the evidence from the known submerged settlements and to consider their wider implications.

\subsection{Conditions of Preservation}

\subsubsection{Sea-Level Change}

The Black Sea basin has undergone varying fluctuations in level and nature throughout the Quaternary. At various times in its history, when eustatic sea levels were low, the Black Sea became isolated from the global ocean system (Badertscher et al. 2011; Özdoğan 2011). The precise timing of these periods, the nature of the basin, changes in salinity and lake levels and the subsequent process of transgression have been fiercely debated (Yanko-Hombach et al. 2007a, b, 2011, 2017; Nicholas et al. 2011; Lericolais 2017; Yanchilina et al. 2017). Understanding the chronology, process and rate of coastal inundation is key to our understanding of prehistoric activity on the shelf, and also to the potential for preservation of submerged archaeological sites.

A central and unresolved issue is the level to which the water in the Black Sea dropped during the Last Glacial Maximum (c. $21 \mathrm{ka} \mathrm{cal} \mathrm{BP)} \mathrm{or}$ Early Neoeuxinian in regional terminology. Lowstand estimates range from c. $120 \mathrm{~m} \mathrm{bpsl}^{1}$ (below present sea level) (Alekseev et al. 1986; FilipovaMarinova 2007; Lericolais et al. 2011; Yanchilina et al. 2017) to $45 \mathrm{~m}$ bpsl (Yanko-Hombach 2007), while modelling of glacio-hydro-isostatic factors

\footnotetext{
${ }^{1}$ All depths in this chapter are given as bpsl (below present sea level) or as minus figures (e.g. $-120 \mathrm{~m}$ ) unless otherwise stated.
} 
(GIA/Glacio-Isostatic Adjustment) indicates a low stand of 140-145 m bpsl (Lambeck and Purcell 2005, Fig. 14a). The water level during the low stand at the LGM informs subsequent models for processes of sea-level rise and reconnection with the Mediterranean, and also indicates the extent of the inhabitable land mass that we may now be missing from the archaeological record on the coastal shelves.

Once isolated, the Black Sea became a brackish to saline lake (1-10\%o) isolated from the Sea of Marmara and the Mediterranean by the Bosphorus sill at c. $40 \mathrm{~m}$ bpsl. During this period, the extent of inflow from the Sea of Azov and freshwater run-off through the major continental river systems, including Late Pleistocene glacial meltwater, is a matter of dispute (YankoHombach et al. 2007a, b, 2011, 2017; Soulet et al. 2013), as is the nature and timing of the transgression and the reconnection with the Mediterranean.

Reconnection with the Mediterranean has variously been put at dates ranging from $8.4 \mathrm{ka} \mathrm{cal}$ BP (Ryan et al. 2003) to $9.3 \mathrm{ka}$ cal BP (Yanchilina et al. 2017) to 10.3-9.5 ka cal BP (Lambeck et al. 2007) and 9.6-9.2 ka cal BP (Nicholas et al. 2011). One hypothesis - the original 'Flood Hypothesis' - is that lake levels were at a low stand of c. $-100 \mathrm{~m}$ at about 10,000 years ago shortly before global sea-level rise overtopped the Bosphorus sill, followed by a rapid inundation as the Black Sea was abruptly reconnected to the Mediterranean (Ryan et al. 1997; Peychev and Peev 2006). An alternative flood hypothesis suggests that the rise in the water level of the Black Sea occurred earlier, at about $12 \mathrm{ka} \mathrm{cal} \mathrm{BP,}$ and had reached the Bosphorus sill before the ingress of the Mediterranean, resulting in a more gradual reconnection (Hiscott et al. 2007). Others again have argued for a gradual reconnection but with greater oscillations of sea level (Pirazzoli, 1996; Balabanov, 2007; Sorokin and Kuprin 2007 Yanko-Hombach et al. 2007a, b). Lericolais (2017) and Yanko-Hombach et al. (2017) provide recent summaries of the various alternatives (see also Kadurin et al., this volume), and Lambeck et al. (2007) and Lambeck and Purcell (2005) provide the most up-to-date modelling of GIA effects in the Black Sea. That the same body of data has produced such significantly different interpretations may seem puzzling. However, the data are drawn from climatology, geology, geophysics, biology and archaeology and were collected by different people at different times for different purposes. Resolution is inevitably varied, and as different research teams privilege different sectors or forms of data, it is perhaps less surprising that there are varied interpretations. Another challenge that has led to this diversity of interpretations is that there have been significant fluctuations in the radiocarbon reservoir effect in the Black Sea during the Late Glacial, resulting in different calibrations of radiocarbon dates derived from shell material (Soulet et al. 2011).

Recently these questions have been the focus of a large-scale project (the Black Sea Maritime Archaeology Project, BSMAP) working on the Bulgarian shelf to collect a new body of integrated data recovered with methodological consistency and to address the nature of transgression after the last glacial maximum. BSMAP has undertaken a geophysical survey of $2000 \mathrm{~km}^{2}$ of the Bulgarian Shelf and conducted an extensive geological core sampling programme which has recovered 92 cores, amounting to almost $400 \mathrm{~m}$ of sediment. At the time of writing, analysis of these cores is well advanced and publication of the results in preparation.

\subsubsection{Palaeogeographic Context}

The nature, timing and rate of the Holocene transgression of the Black Sea are important in assessing the potential for preservation of submerged prehistoric sites. Clearly different hypotheses result in different models of the extent of submerged coastal shelf, and different narratives of the impact of transgression. However, it is generally agreed that many prehistoric sites are likely to have been located in areas that are now inundated. The archaeological record also supports this, although after initial discoveries on the Bulgarian coast during the 1980s and 1990s, further underwater exploration in the Black Sea has revealed little or nothing in the way of new prehistoric 
finds (Ballard et al. 2001; Sturt et al. 2018, see also Kadurin et al., Chap. 21, this volume).

The Bulgarian coastline extends for $432 \mathrm{~km}$ from Cape Sivriburun in the north (marking the state border with Romania) to the Rezovska River in the south (marking the state border with Turkey). The coastline comprises a rich mosaic of relict and modern land forms, e.g. denudation surfaces, marine terraces, cliffs and ravines formed by erosion, landslides, sandy beaches with dunes, river mouths, inlets and lagoons (Stancheva 2013; Stanchev et al. 2013).

Neotectonic movements, while generally understated, may be relevant to resolving discrepancies between different low-stand elevations across the western shelf (Glebov and Shel'ting 2007; Meriç et al. 2018). The Black Sea Basin originated as a back-arc basin in the early Cretaceous, with extension and thinning of the Earth's crust at a subduction plate boundary. Ongoing deformation similar to that in the Aegean has resulted in long-term subsidence especially around the basin margins with more localised episodes of uplift and subsidence on fault zones, but there is little evidence of geologically recent tectonic movement in the Black Sea coastal zone of SE Bulgaria (Nikishin et al. 2003; Stephenson and Schellart 2010; Özdoğan 2011; Caraivan et al. 2017; Kalafat 2017; see also Galanidou et al., Chap. 19, this volume). Archaeologists have inferred upward tilting of the Bulgarian coast in the north from the different depths of on-land and underwater Late Eneolithic and Early Bronze Age sites in different areas (Draganov 1995, p. 225; Angelova and Draganov 2003, p 10). Orachev (1990) also infers vertical uplift in the north from changes in coastal geomorphology and the partial collapse and submergence of the Thracian city of Byzone on Cape Chiracman during an earthquake in the first-century BC. However, uncertainties about the degree and extent of earth movements and the depth of submerged settlements in relation to contemporaneous sea level preclude further interpretation of tectonic effects.

The bathymetry of the Black Sea (see YankoHombach et al. 2017, Kadurin et al., Chap. 21, this volume) indicates that the broadest shelves are located in the west (Bulgaria and Romania) and the north-west (Ukraine), and it is unsurprising that these areas have been the main focus for underwater research, most of which has been devoted to geological issues. This research has demonstrated the preservation of Quaternary features such as palaeorivers, submerged ridges, potential dune formations and peat horizons (Giosan et al. 2009; Lericolais 2017; Yanchilina et al. 2017; Yanko-Hombach et al. 2017; Kadurin et al., Chap. 21, this volume). It is worth bearing in mind that these are not the only contexts in which submerged sites can be preserved; there is also potential for underwater cave sites, which are more likely to be found along the southern and eastern Black Sea coasts.

In Bulgaria, the average width of the shelf down to the $120 \mathrm{~m}$ bathymetric contour is c. $40-50 \mathrm{~km}$ giving a maximum area of submerged landscape of as much as $12,380 \mathrm{~km}^{2}$ (Fig. 20.1). Considering that the land territory of Bulgaria totals c. $111,000 \mathrm{~km}^{2}$, the potential survey area for underwater exploration relating to human presence and utilization of marine resources is quite large.

The Romanian coast to the north is geomorphologically similar to that of Bulgaria, extending for $245 \mathrm{~km}$, with coastal inlets and shallow bays, and is just as likely to contain submerged prehistoric sites as Bulgaria (see Caraivan et al. 2017). The UNESCO report on Romanian underwater cultural heritage (UNESCO 2010a) references the potential for submerged Eneolithic and Neolithic sites and refers to locations at Taşaul and Techirghiol, located only c.50 km north of the famous Bulgarian Neolithic sites of Durankulak and the submerged necropolis site at Shabla. One consideration for the preservation and visibility of submerged prehistoric sites on the Romanian coastal shelf is the likelihood that sites are buried under sediments deposited from the Danube.

The Ukrainian shelf in the north-west is the widest continental shelf, extending out to $220 \mathrm{~km}$ and representing $16 \%$ of the Black Sea area. This shelf has a long history of geological research, but no submerged prehistoric sites have yet been discovered in this region, apart from isolated flints found in sediment cores during geological surveys (Yanko-Hombach et al. 2017; Kadurin et al., Chap. 21, this volume). 


\subsection{Archaeological Context}

The submerged prehistoric sites so far discovered in the Black Sea are located on the Bulgarian coast. It is likely that this has more to do with a tradition of maritime archaeological research in the region rather than differential preservation. Underwater archaeological fieldwork has taken place in Bulgaria over the past 60 years, beginning with the pioneering work of scholars such as Lyuba Ognenova-Marinova and Mihail Lazarov. An important impetus to the study of prehistoric material was the establishment of the Centre for Underwater Archaeology (CUA) in Sozopol in 1978. This was the first institute to focus on underwater archaeology and the protection and management of underwater cultural heritage in the Black Sea. Many of the investigations of underwater settlements were made in the 1980 s and 1990s under the leadership of the late Hristina Angelova, who was Director of the CUA from 1993 to 2016 (Porozhanov 1991, 2004; Ivanov 1993; Draganov 1995, 1998; Angelova and Draganov 2003; Velkovsky et al. 2013).

Palaeolithic and Mesolithic sites in this region are rare. For the Late Palaeolithic, there is the site of Little Cave near the town of Beloslav in the Varna district, with flint tools and associated faunal remains dating to c.14,000-12,000 cal BP (Todorova 1978). Little is known about the Mesolithic generally, apart from the site of Pobiti Kamuni, which contains one of the largest Mesolithic assemblages in south-eastern Europe with more than 12,500 stone artefacts. The finds are unstratified but are attributed on typological grounds to a period of c. 10,000 cal BP (c. 8000 cal BC) (Margos 1972; Todorova 1995). Otherwise, there appears to be a hiatus of more than 1000 years before the appearance of Neolithic farmers in Bulgarian territory.

One suggestion is that the rarity of Mesolithic sites is due to the fact that they were located along palaeocoastlines and palaeorivers that were subsequently inundated by marine transgression during the Holocene (Chapman 1989; Gurova and Bonsall 2014). Certainly, the potential for discovery of Mesolithic sites on the submerged shelf is important, not only for understanding Mesolithic subsis- tence and settlement but also for understanding the process of Neolithization within the region.

The earliest Neolithic cultures known in Bulgaria appear at about $6500 \mathrm{cal} \mathrm{BC}$ and have obvious affinities with the Neolithic in Anatolia (Table 20.1; Boyadziev 1995; Todorova 1995). The distribution of sites is concentrated along the major river systems in central, western and northern Bulgaria, and there is almost no evidence of settlement in the Black Sea coastal region until the Eneolithic (Chalcolithic) period. As for the Mesolithic period, so too for the Neolithic period, there is the question of a possible Neolithic presence on now-submerged territory, which might account for the rarity of Early and Middle Neolithic sites in the coastal region. However, no submerged settlements have yet been found earlier than the Eneolithic period, possibly because sites of earlier date lie at a greater depth than the underwater sites found so far and are buried under a greater thickness of riverine and lacustrine sediments.

The Eneolithic period is marked by the appearance of the Varna culture in the coastal region of

Table 20.1 Chronology of principal subdivisions of the archaeological sequence in Bulgaria from the beginning of the Neolithic to the end of the Early Bronze Age. Note that the boundaries are approximate and that some may be time-transgressive, that relatively few sites have been directly dated by radiocarbon dating and that many sites and culture layers are dated by comparison of their ceramic typology with better dated sites elsewhere. After Boyadziev (1995) and Todorova (1995)

\begin{tabular}{l|l|l|l}
\hline \multirow{2}{*}{ Period } & \multirow{2}{*}{ Sub-period } & \multicolumn{2}{l}{ Date range } \\
\cline { 3 - 4 } & Eal BC & Cal BP \\
\hline Neolithic & Middle & $6500-$ & $8450-$ \\
& & 5450 & 7400 \\
\hline & Late & $5150-$ & $7400-$ \\
& & $5150-$ & 7100 \\
\hline Eneolithic & Early & 4850 & $6800-$ \\
\hline & & $4550-$ & $6800-$ \\
& Middle & $4550-$ & 6500 \\
\hline & & 4450 & $6500-$ \\
& Late & $4450-$ & $6400-$ \\
\hline Transitional & & 3850 & 5800 \\
Period & & $3850-$ & $5800-$ \\
\hline Bronze Age & Early & $3200-$ & $5150-$ \\
& & 2500 & 4450 \\
\hline
\end{tabular}


NE Bulgaria, famous for its evidence of copper mining, fortified dwellings, palaces and shrines and its large cemeteries, notably at Varna, dated at 4650-4450 cal BC, and Durankulak, with 294 and 1204 graves, respectively (Todorova 1995, Higham et al. 2007). The burial evidence indicates differences of social rank with the individuals of highest status associated with rich grave goods of copper and gold.

The Eneolithic period is followed by the enigmatic Transitional Period, which witnessed the demise of the Varna culture and reduced evidence of settlement along the Bulgarian coast more widely in the centuries between about 3850 and 3200 cal BC (Table 20.1). This reduction in settlement evidence is variously attributed to social collapse or environmental processes such as climate change and flooding of productive farm land by sea-level rise (Todorova 1995). This period was followed, in its turn, by the renewed appearance of settlements after c. $3200 \mathrm{cal} \mathrm{BC}$, associated with the Early Bronze Age.

It is during the Eneolithic and Early Bronze Age periods that evidence of underwater settlements is best represented.

\subsection{Underwater Sites}

There are 18 underwater sites in the SPLASHCOS Viewer (Fig. 20.2; Table 20.2). At least six sites appear to have in situ cultural deposits, and that figure could be higher. However, relatively few sites have been investigated by systematic excavation, and many have been damaged by construction work or dredging and were investigated under less than ideal conditions, sometimes as rescue operations, and details are not available or easily accessible in many cases. Dating is also often based on typochronological comparisons of pottery types and rarely on direct radiocarbon dates. One site, Shabla, has two human burials, which appear to be the remains of a necropolis, and one (Stomoplo) is of unknown status.

Of these sites, Shabla is on the northern coast of Bulgaria,13 are located in the Varna-Beloslav Lake area (Ivanov 1993) and five along the southern Bulgarian shore (Draganov 1995; Filipova-

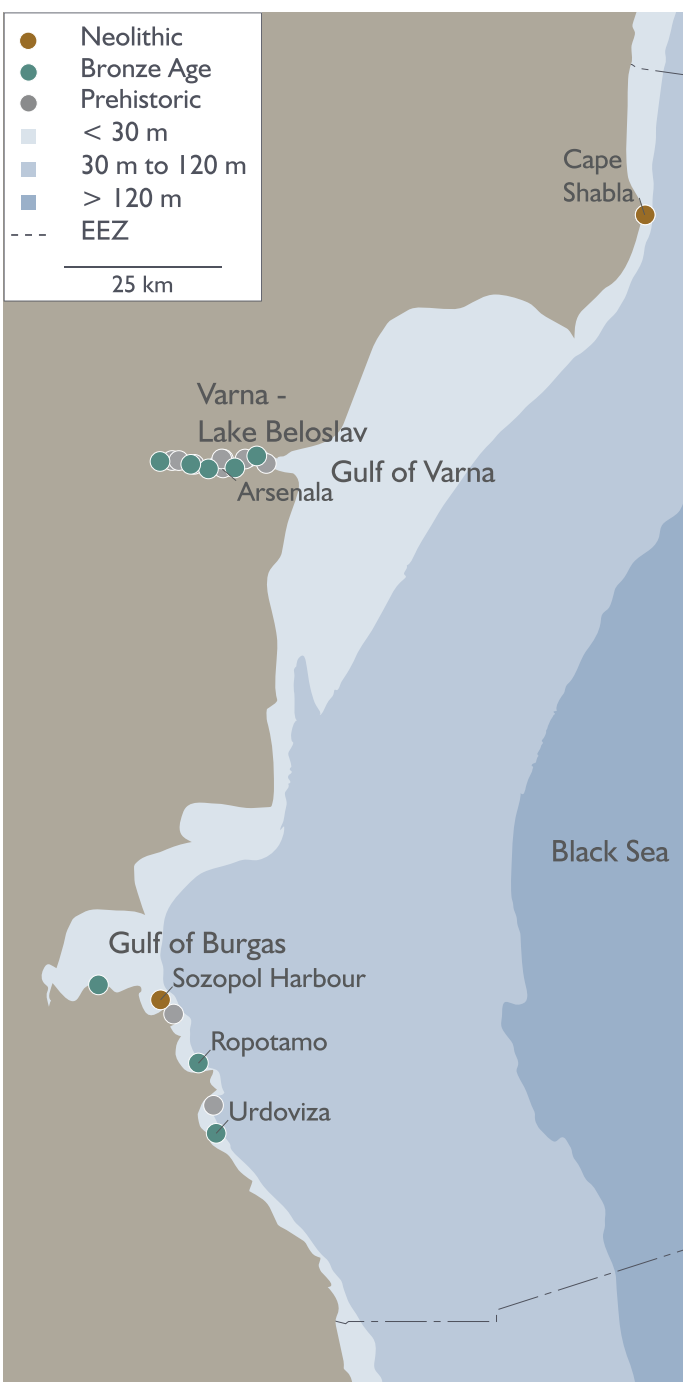

Fig. 20.2 Detailed map of submerged sites on the Bulgarian coast. Site information from the SPLASHCOS Viewer http://splashcos-viewer.eu. Drawing by Moritz Mennenga

Marinova et al. 2011). Ten of these have material dating to the later phases of the Late Eneolithic (c 4500-3850 cal BC) (Ivanov 1993; Draganov 1995; Lazarov 1996), and 17 sites contain cultural remains belonging to the Early Bronze Age (3200-2500 cal BC).

All sites are in shallow water at depths ranging from c. 3.5 to $9 \mathrm{~m}$. Organic remains of wood have been recovered from six sites, animal bones from four and human bone from the Shabla burials (Table 20.2) 
Table 20.2 List of underwater archaeological sites, showing chronology, maximum depth bpsl and the presence or absence of wood preservation and animal or human bone. Eneo Eneolithic; EBA Early Bronze Age. The category of site type 'collection of finds' means that the information about context and recovery methods is not good enough to establish the presence of an in situ cultural layer, but equally that cannot be ruled out. Depth measurements are approximate. The SPLASHCOS Viewer data has 22 entries, 2 separate entries for Shabla (based on the different depths of the two burials) and 3 separate entries for Sozopol, representing deposits in different locations within Sozopol harbour. We have amalgamated these in this table

\begin{tabular}{|c|c|c|c|c|c|c|}
\hline \multirow[b]{2}{*}{ Region/site name } & \multirow[b]{2}{*}{ Site Type } & \multicolumn{2}{|c|}{$\begin{array}{l}\text { Archaeological } \\
\text { period }\end{array}$} & \multirow[t]{2}{*}{ Max depth m } & \multirow[t]{2}{*}{ Bone } & \multirow[t]{2}{*}{ Wood } \\
\hline & & Eneo & EBA & & & \\
\hline \multicolumn{7}{|l|}{ Cape Shabla } \\
\hline Shabla I \& II & Human burials & $\sqrt{ }$ & & $3.5-6.5$ & $\sqrt{ }$ (Human) & \\
\hline \multicolumn{7}{|l|}{ Varna Group } \\
\hline Hristo Botev & Collection of finds & & $\sqrt{ }$ & 8 & & \\
\hline Morfot & Collection of finds & $\sqrt{ }$ & $\sqrt{ }$ & 9 & & \\
\hline Topolite & Collection of finds & & $\sqrt{ }$ & 8 & & \\
\hline Ezerovo I & Settlement in situ & $\sqrt{ }$ & $\sqrt{ }$ & 8.5 & & $\sqrt{ }$ \\
\hline Ezerovo II & Settlement in situ & $\sqrt{ }$ & $\sqrt{ }$ & 8.5 & & $\sqrt{ }$ \\
\hline Arsenala & Settlement in situ & $\sqrt{ }$ & $\sqrt{ }$ & 7 & $\sqrt{ }$ & $\sqrt{ }$ \\
\hline Ladjata & Collection of finds & & $\sqrt{ }$ & 7.5 & & \\
\hline Strashimirovo I & Collection of finds & $\sqrt{ }$ & $\sqrt{ }$ & 5 & & \\
\hline Strashimirovo II & Collection of finds & & $\sqrt{ }$ & 4 & & \\
\hline Beloslav & Collection of finds & $\sqrt{ }$ & $\sqrt{ }$ & 8 & & \\
\hline Povelyanovo & Collection of finds & $\sqrt{ }$ & $\sqrt{ }$ & 6.5 & & \\
\hline Baltata & Collection of finds & & $\sqrt{ }$ & 5 & & \\
\hline Rodopa & Collection of finds & $\sqrt{ }$ & $\sqrt{ }$ & 6 & & \\
\hline \multicolumn{7}{|c|}{ South Bulgaria group } \\
\hline Atiya & Collection of finds & & $\sqrt{ }$ & 9 & & \\
\hline Sozopol & Settlement in situ & $\sqrt{ }$ & $\sqrt{ }$ & $5-8$ & $\sqrt{ }$ & $\sqrt{ }$ \\
\hline Ropotamo & Settlement in situ & & $\sqrt{ }$ & $4-5$ & $\sqrt{ }$ & $\sqrt{ }$ \\
\hline Stomoplo & Unknown & & & & & \\
\hline Urdoviza (Kiten) & Settlement in situ & & $\sqrt{ }$ & $6-7$ & $\sqrt{ }$ & $\sqrt{ }$ \\
\hline Totals & 19 & 10 & 17 & & 4 & 6 \\
\hline
\end{tabular}

Although full details are lacking at many sites because of the circumstances of discovery, nevertheless it appears from the recovery of pottery and other indications including remains of wooden structures and abundant artefacts that the sites were substantial settlements. More detailed information including palaeoenvironmental data have been obtained from excavations conducted at Sozopol, Urdoviza and Ropotamo.

\subsection{Northern Bulgaria}

\subsubsection{Cape Shabla}

This submerged prehistoric necropolis has been recorded in the area of Cape Shabla (Peychev and
Peev 2006; Peev 2008a, 2009). Two burials have been excavated between c. $6.5 \mathrm{~m}$ and $3.5 \mathrm{~m}$ bpsl and are dated to the Eneolithic period (Fig. 20.3). The necropolis is related to the on-land settlements of Shabla I and/or Shabla II (Todorova 1984). Other than these two burials, the necropolis has not been further investigated.

\subsubsection{The Varna-Beloslav Lake Area}

Varna Lake is a typical inlet situated in the western part of the Gulf of Varna (Fig. 20.4). It is the largest inlet by volume and depth on the Bulgarian coast with an area of $17 \mathrm{~km}^{2}$, a maximum depth of $19 \mathrm{~m}$ and a water volume of 166 million $\mathrm{m}^{3}$. It was formed by rising sea levels during the 


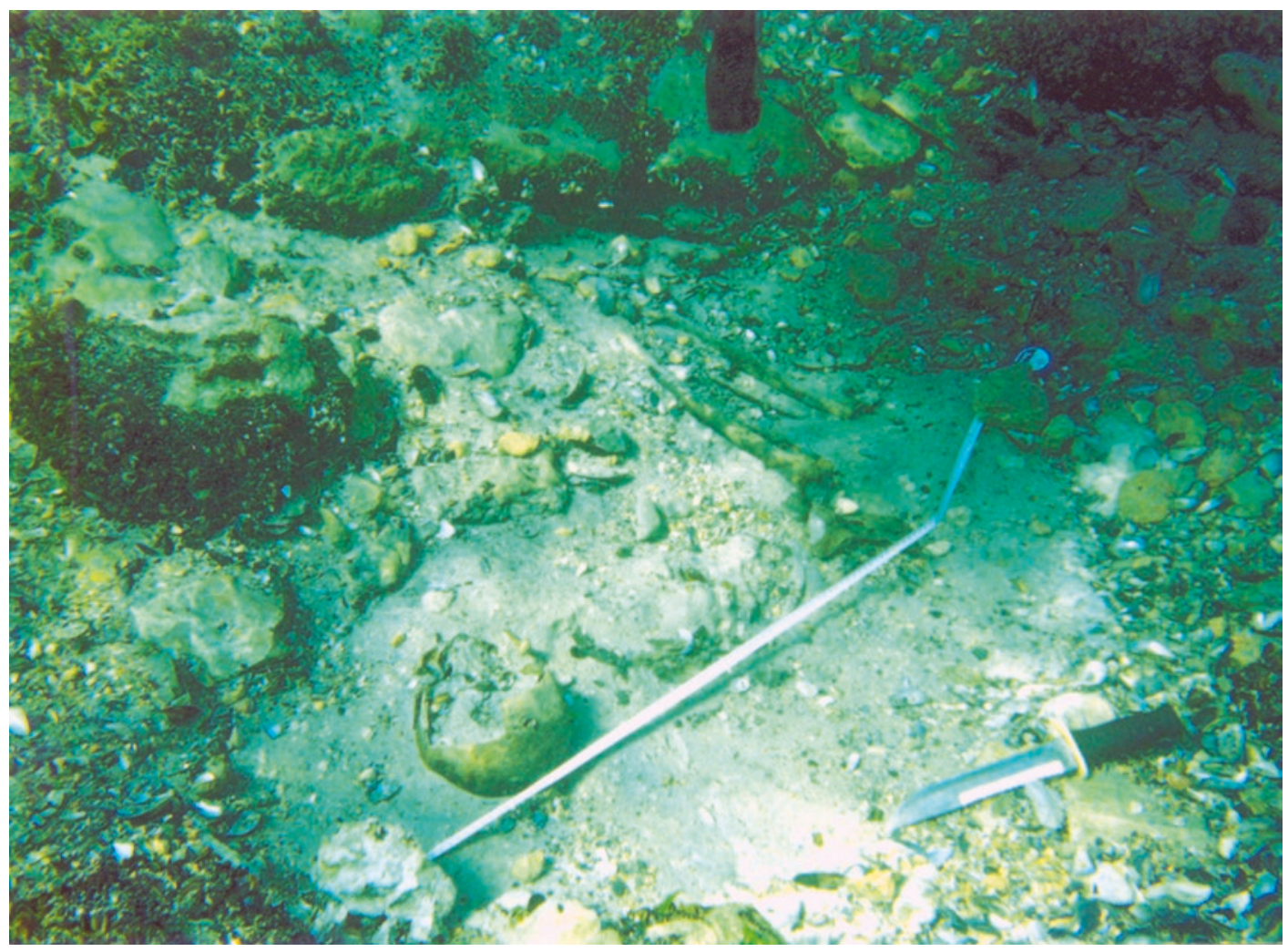

Fig. 20.3 Underwater photo of prehistoric grave at depth $3.5 \mathrm{~m}$ below present Black Sea level off Cape Shabla. Photo by Damyan Damyanov

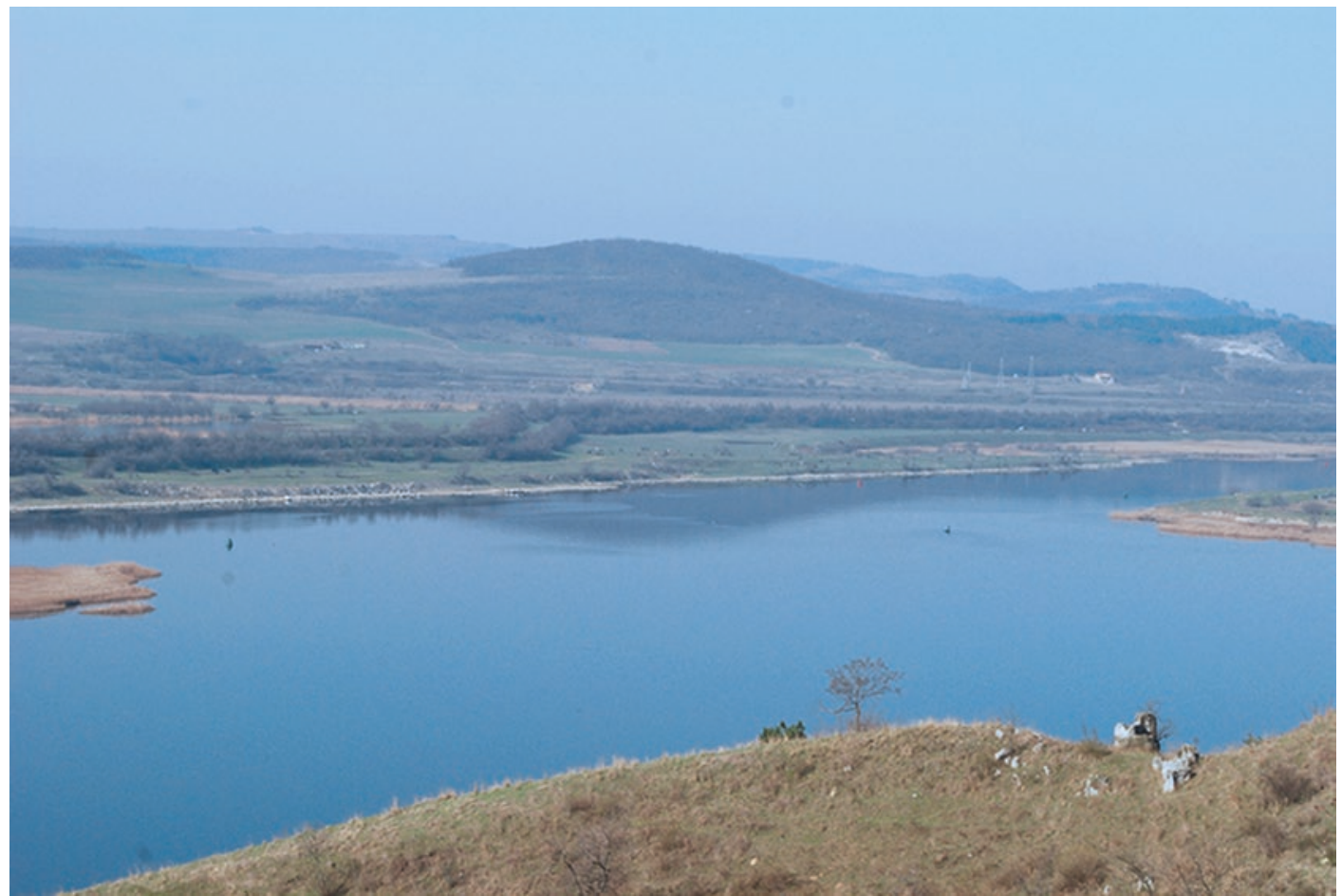

Fig. 20.4 View of Lake Varna, looking south. Photo courtesy of Museum of Archaeology Varna 
Holocene, after c. 7870 cal BP (5870 cal BC) according to Filipova-Marinova et al. (2016). The basin remained a freshwater lake supplied by groundwater and inflowing rivers, with a limited connection to the Black Sea, until it was modified in 1909 to connect with Varna Bay through an artificial channel, after which it became a brackish lagoon. In 1975 a new canal was dug with a depth of $12 \mathrm{~m}$. As a result, the salinity of the water increased to 15-16\%o (Peev 2008b). Today, the lake is separated from the sea by the constantly growing Asparuhovo sand spit (Dachev 2003) and is divided into two lakes, Lake Varna and Lake Beloslav, resulting from progressive accumulation of sediment and decreased river flow.

Drilling surveys located $650 \mathrm{~m}$ south of the dredged shipping channel have revealed a 51.4 m-deep sequence of Holocene sediments indicating oscillating sea-levels (Popov and Mishev 1974). The sequence is as follows (from the base upwards):

\section{A peat layer $0.6 \mathrm{~m}$ thick}

2. Marine sediments up to $18 \mathrm{~m}$ thick containing a fauna dated to the Holocene

3. Subaerial deposits with $1.5 \mathrm{~m}$ of peat

4. Sand mixed with gastropod shells, $18 \mathrm{~m}$ thick, indicating marine conditions

5. A third peat layer $1 \mathrm{~m}$ thick and accumulated clayey sand

This suggests that there were two cycles of marine transgression followed by minor regression. This sequence is of particular interest since, although not fully dated, it indicates a pattern of fluctuations in sea level similar to evidence indicated by stratigraphic sections in underwater archaeological settlements and by pollen sequences, as discussed below.

\subsubsection{Arsenala}

Along the shorelines of the Varna-Beloslav Lake, the remains of eight submerged settlements from the second stage of the Eneolithic have been found (Fig. 20.2; Ivanov 1993). The earliest dis- covery was on the north shore of the lake near the village of Strashimirovo, first mentioned in 1921 by H. and K. Shkorpil (1921). However, only one site, Arsenala, has undergone underwater excavations (Fig. 20.5). An area of $25 \mathrm{~m}^{2}$ was excavated and revealed two cultural layers identified as dating to the Eneolithic and the EBA, respectively. The EBA layer reaches a thickness of $3.5 \mathrm{~m}$. This overlies a sterile layer c. $0.9 \mathrm{~m}$ thick, which is rich in marine molluscs. The Eneolithic lies beneath this in a layer c. $0.9 \mathrm{~m}$ thick with remains of wooden posts used for house construction, ceramics and animal bones (Ivanov 1987). The Eneolithic layer includes decorated ceramics from the Varna culture (Fig. 20.6), and the EBA layer is notable for cult items including male and female figurines.

The pollen analytical work of FilipovaMarinova et al. (2016) in Lake Varna shows two episodes of deforestation and cereal cultivation with an interval in between of re-afforestation and reduction in indicators of human influence. The first episode of deforestation is dated to 6140-5820 cal BP (4190-3870 cal BC), corresponding to the Late Eneolithic occupation at Arsenala. The second episode begins at $5500 \mathrm{cal}$ $\mathrm{BP}$ (3550 cal BC) and corresponds to the middle

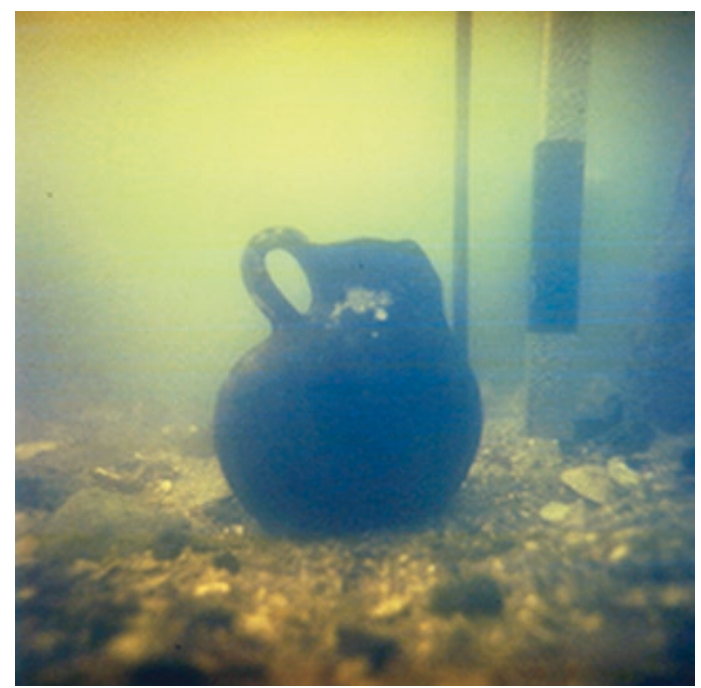

Fig. 20.5 Early Bronze Age pottery shown in situ at the submerged site of Arsenala. Scale in $10 \mathrm{~cm}$ intervals. Photo courtesy of Museum of Archaeology Varna 1988 
of the Transitional Period (Table 20.1), while the interval between lasted for 320 years and is consistent with the occupational hiatus at Arsenala associated with marine sediments.

\subsection{Southern Bulgaria}

\subsubsection{Urdoviza}

This site in the bay of Kiten (a name by which the site is also referred to in the literature) was excavated between 1986 and 1989 and again in the 1990s over a total area of $925 \mathrm{~m}^{2}$ (Draganov 1995; Angelova and Draganov 2003; Stanimirov 2003; Porozhanov 2004). Interestingly, the prehistoric material was discovered by chance during an underwater investigation of a post-Medieval shipwreck, beneath which the prehistoric deposits were revealed. The seabed at this location is $6.3 \mathrm{~m}$ bpsl, and the cultural deposit extends from this level down to $-7.05 \mathrm{~m}$ (Fig. 20.7). Bathymetric and sidescan surveys of the wider surroundings indicate that, when occupied, the settlement was 500-600 m from the nearest shoreline and sea level at that time was at $-8 \mathrm{~m}$.

Over 3000 pots or potsherds of typical EBA forms were recovered (Fig. 20.8), many of which are complete vessels, supposedly surviving because the deposits were quickly sealed by marine deposits after inundation and abandonment of the settlement. Other cultural remains are stone and antler artefacts, bone awls and spatulae made from bird bone, clay figurines, a bone amu- let, two stone moulds for making bronze axes, a bronze knife and parts of horse bridles.

Excavations also revealed at least 300 timber posts mostly of oak. Some of these were vertical posts driven vertically into the ground and attached to horizontal members by jointing and ropes (Fig. 20.7). Draganov (1995) describes fragments of floor and wall daub, hearths and clay floor coverings, and suggests that the horizontal timbers were designed to support dwelling structures raised slightly above a ground surface that was marshy or liable to flooding. Dendrochronological analysis of 83 of these timbers produced a 285 -year long tree ring chronology-one of the longest from Eastern Europe and the Aegean-and evidence of 5 building phases at Urdoviza over a 64-year period of occupation between 4778 and 4715 cal BP (28282765 cal BC) (Kuniholm et al. 1998, 2007).

The faunal remains comprise over 7000 specimens and are dominated by wild animals, especially aurochs (Bos primigenius), red deer (Cervus elaphus), roe deer (Capreolus capreolus) boar (Sus scrofa) and various bird species. There are also numerous bones of tuna and dolphin, suggesting the use of boats for offshore and deep-water marine exploitation. Domestic animals are cattle and horse, the latter including 40 skulls, 20 of which are intact and arranged in such a way as to suggest some cultic significance along with 5 pairs of aurochs horns apparently arranged in a deliberate pattern. Pollen data show evidence of forest clearance but no indications of cereal agriculture.
Fig. 20.6 Pottery from Arsenala. Photo courtesy of Museum of Archaeology Varna 1988

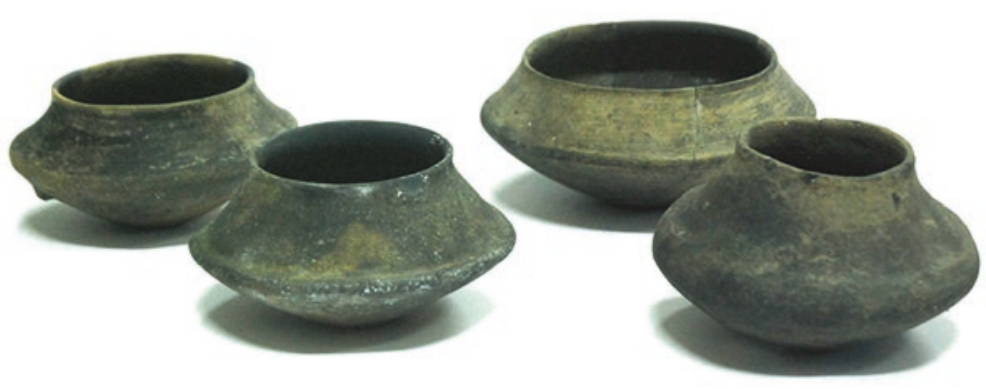


Fig. 20.7 Stratigraphic section through the cultural layer at Urdoviza showing the stratigraphy and some of the timber posts.

Drawing by Geoff Bailey, after Angelova and Draganov (2003, Fig. 3, p. 15)
Fig. 20.8 Pottery from the Early Bronze Age submerged settlements of Ezerovo and Urdoviza. Photo courtesy of the Centre for Underwater Archeology, Sozopol and the Museum of Archaeology, Varna
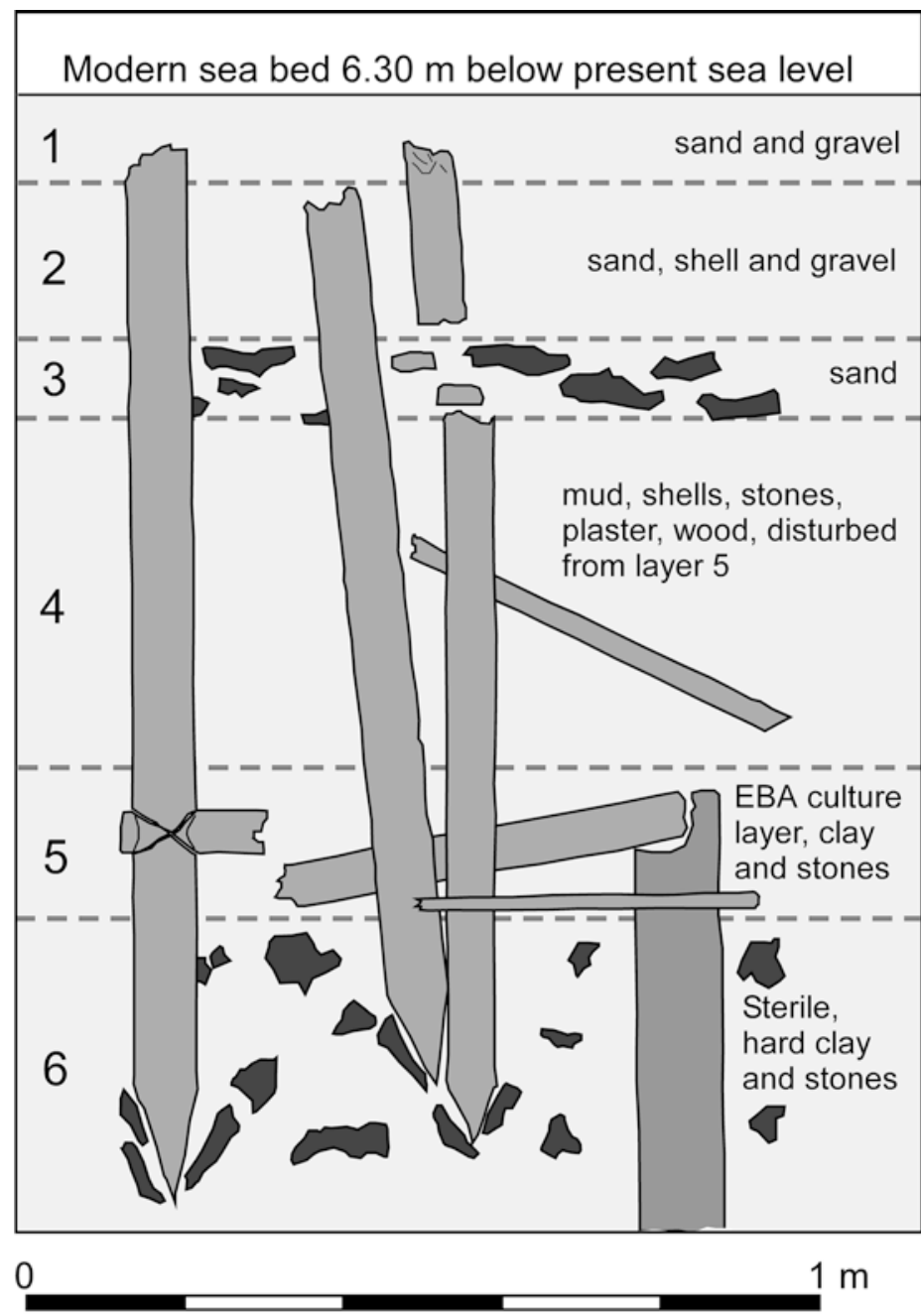

\section{- - - Layer boundary 1-6 Layer numbers}

Stones

Worked timber

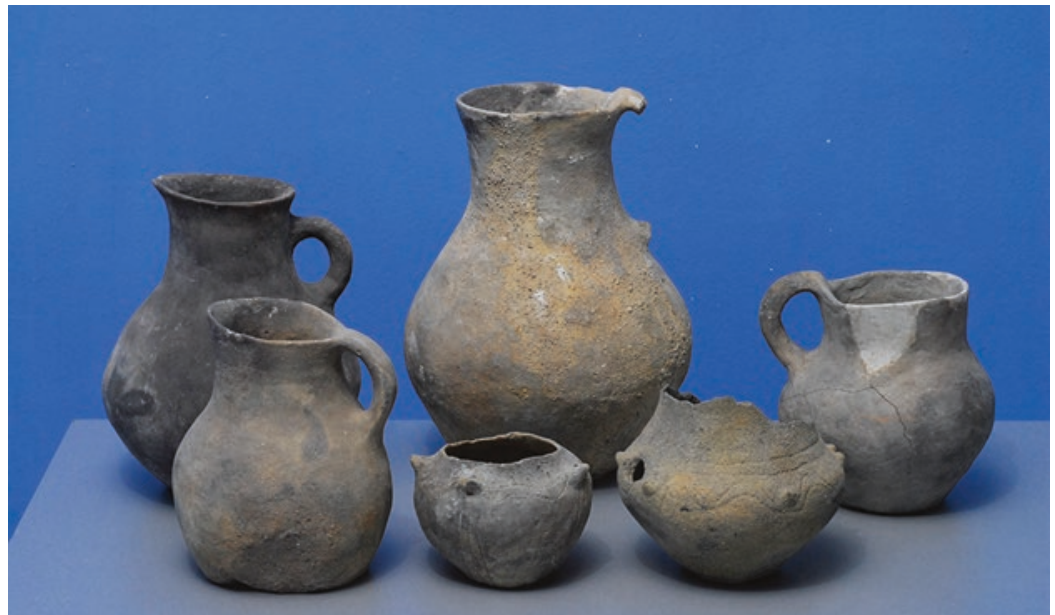




\subsubsection{Sozopol}

Two closely adjacent areas of submerged settlement were investigated by excavations in Sozopol harbour in the 1980s and the early 1990s, one area with material of Eneolithic date and the other EBA (Draganov 1995, 1998; Angelova and Draganov 2003; Filipova-Marinova et al. 2011). Both produced abundant ceramics, timber posts and faunal remains. The results have been reported in less detail than at Urdoviza. Spassov and Iliev (1994) examined 941 identifiable bone remains indicating a faunal assemblage similar to Urdoviza. Wild animals dominate, especially aurochs, red deer and fallow deer, and domestic animals included a significant proportion of sheep and goat (a difference from Urdoviza) as well as domestic cattle and some domestic pig. Numerous bird bones are present, mostly of species associated with coastal wetlands, numerous bones of two species of dolphins, the bottlenosed dolphin (Tursiops truncatus) and the common dolphin (Delphinus delphis), and just two vertebrae of tuna (Thunnus thunnus). Although the provenance of some of the bones was uncertain, it is clear that the faunal composition of the two settlements, and especially the emphasis on marine resources, is broadly similar. Pollen analysis and radiocarbon dating of sediment cores from Sozopol harbour shows that both the Eneolithic and EBA periods of settlement were associated with forest clearance and the presence of cultivated wheat and barley and weeds typically associated with cultivation (FilipovaMarinova et al. 2011), marking a difference from Urdoviza where evidence of cereal cultivation is absent

\subsubsection{Ropotamo}

In conjunction with the offshore coring programme, the Black Sea Maritime Archaeology Project reviewed the available data relating to submerged prehistoric material along the Bulgarian coast (summarised above) with a view to identifying a suitable target for more detailed investigation of the relationship between archae- ological material and sea-level change. Work has focused on the mouth of the Ropotamo River. In the 1980s, dredging activities reportedly recovered Eneolithic and EBA ceramics and timber structures (Karayotov 1990). Although little detail was published, there was a clear possibility of locating the original source of the material.

In June 2017, two trenches each $5 \mathrm{~m}^{2}$ were excavated and revealed a deeply stratified deposit more than $3 \mathrm{~m}$ thick with its surface on the seabed at c. $2.3 \mathrm{~m}$ below present sea level (Fig. 20.9). Below modern, mobile seabed sediments, large quantities of Ottoman ceramics were found above a dense deposit of Byzantine material that included ceramics, tile, mortar and wood, possibly from waterside infrastructure that had subsided into the water due to tectonic activity. Below this was a thick layer of marine sediment in which some Greek ceramic sherds were found. Below this at $2.5 \mathrm{~m}$ below the seabed, Bronze Age material was discovered: ceramics identified as EBA material, including a whole vessel (Fig. 20.10), burnt clay from domestic hearths and structural timber. Radiocarbon dating from three of the in situ vertical timber posts suggests construction between 3080 and 2970 cal BC (5050-4920 cal BP). These remains had been covered by marine deposits in which there is a high density of oyster shell, indicating inundation. The relatively uneroded condition of the archaeological material suggests that inundation may have been rapid, creating an environment of shallow flowing water with high levels of light and oxygen suitable for the lodging of oyster spat. Archaeological excavation is ongoing.

Initial results of this new work at Ropotamo are consistent with the earlier findings from Urdoviza and Sozopol for a sea level during the EBA period between c. $5 \mathrm{~m}$ and $8 \mathrm{~m}$ bpsl, with a subsequent rise in sea level, rapidly inundating the settlements and forcing their abandonment.

\subsection{Discussion}

Both underwater archaeological sites and palaeoenvironmental sequences provide a consistent picture of two phases of settlement on the 


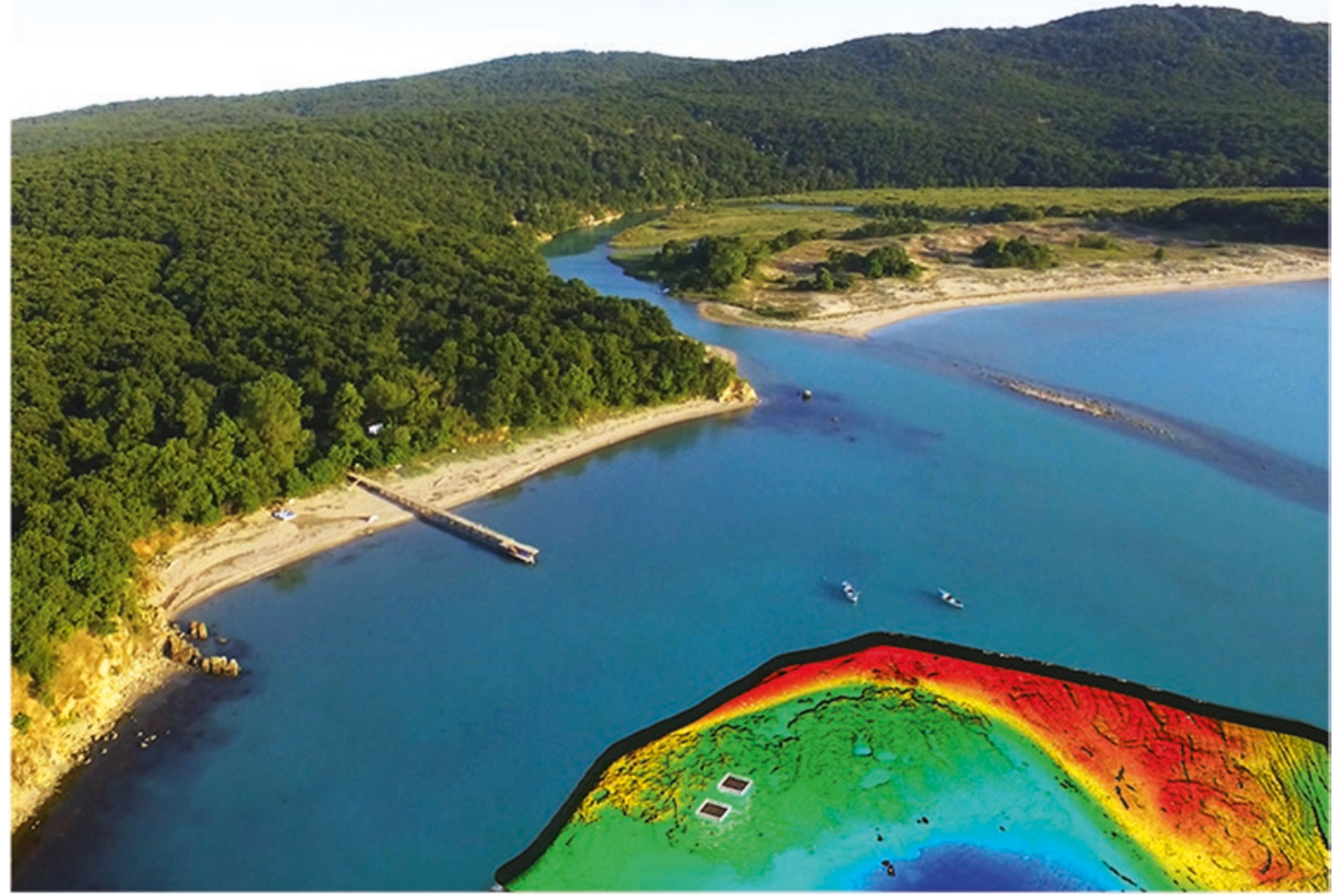

Fig. 20.9 Ropotamo Bay. Aerial view of the site overlaid with bathymetry in order to show location of the underwater excavation trenches. Photo by Rodrigo Pacheco-Ruiz, University of Southampton, courtesy of BSMAP

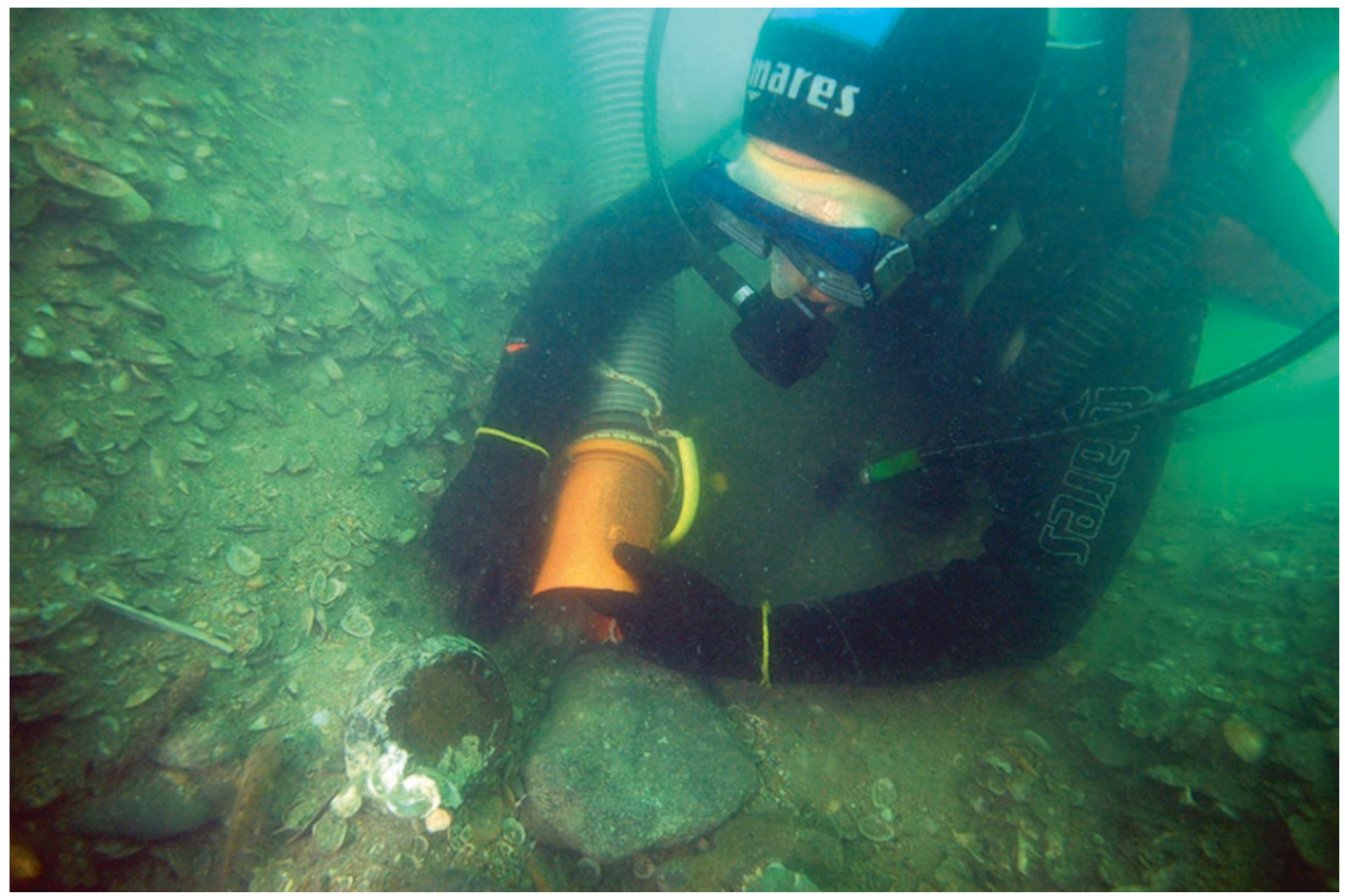

Fig. 20.10 Professor Kroum Batchvarov (University of Connecticut) excavating a complete EBA ceramic bowl at Ropotamo. Note the thick layer of oyster shells immediately above it. Photo by Jon Adams 
Bulgarian coast between about c. 4400 and 2500 cal BC, the first associated with the Late Eneolithic period (c. $4450-3850 \mathrm{cal} \mathrm{BC}$ ), and the second associated with the EBA (c. 3200$2500 \mathrm{cal} \mathrm{BC}$ ). There is some variation and margin of error in these date ranges, but all the evidence points to a hiatus in occupation along the Bulgaria coast, with abandonment of settlements and the re-establishment of forested conditions. The length of this interval is debated, and more excavation and dating are needed.

These two periods of occupation witnessed the establishment of settlements along the sheltered shorelines of inlets and river estuaries near the coast, with timber-built platforms and dwellings established on low-lying ground liable to flooding, forest clearance and cereal agriculture. There was some dependency on domestic animals, but also an emphasis on hunting of wild animals and marine resources including tuna fish and dolphins, the latter indicating the probable use of boats. The occupational hiatus seems to have been widespread within the Bulgarian Black Sea coastal region, with evidence for the expansion of forests and abandonment of villages in a number of locations. A variety of causes have been invoked to explain these changes including environmental changes - of sea-level or climate-and social factors (Todorova 1995).

The relationship of these underwater settlements to sea-level change raises two questions. The first is why settlements dated between c. 4500 and $2500 \mathrm{cal} \mathrm{BC}$ were located on shorelines that are now underwater in association with a sea level as much as $8 \mathrm{~m}$ bpsl on the Bulgarian coastline. This is long after a connection between the Black Sea and the world oceans had become established, and a period when eustatic sea level was within a metre or two of the modern level. Lambeck and Purcell (2005) have modelled the effect of glacio-hydro-isostatic movements of the Earth's crust on relative sea level throughout the Mediterranean and the Black Sea. Their models indicate that relative sea level on the coast of Bulgaria at $6000 \mathrm{cal} \mathrm{BP} \mathrm{(c.} 4000 \mathrm{cal} \mathrm{BC}$ ) was about -5 $\mathrm{m}$ (Lambeck and Purcell 2005, Fig. 14f). Allowing for the margins of error in the various measurements involved, this might be sufficient to account for the depth of the underwater settlements. Whether an additional component of vertical tectonic movement resulting from plate motions needs to be involved remains uncertain.

The second question is the apparent evidence for a temporary sea-level oscillation between the Eneolithic and the Early Bronze Age, involving a temporary and short-lived increase in relative sea level followed by a retreat. The evidence of stratigraphic sequences, described above, which show marine sediments sandwiched between terrestrial deposits, provides some support for this fluctuation in height of sea level, or in rate of sea-level variation. How widespread it was, and the causes of it, whether resulting from regional tectonic movements or geomorphological processes of lateral shoreline retreat and advance, remain unclear, and work is ongoing to resolve this problem (compare Filipova-Marinova 2007 and Kislov 2018).

Whatever the causes of this sea-level fluctuation, it offers support for the hypothesis that the gap in occupation between the Eneolithic and the Early Bronze Age was due to a temporary rise in relative sea level that removed low-lying land on the coast that had provided favourable conditions for economic subsistence, including fertile soils for crop cultivation and wetlands rich in bird life.

These submerged settlements demonstrate the excellent quality of evidence that can be preserved as a result of rapid inundation and submergence of archaeological material in anaerobic sediments. They are also testament to the potentially disruptive effects of sea-level rise on pre-existing patterns of social and economic organisation. Both factors have implications for earlier periods. In particular, they raise the question of whether earlier settlements of a similar nature existed along palaeoshorelines that are now submerged, with archaeological settlements protected beneath marine sediments. As noted earlier, the absence of Mesolithic and Neolithic sites on the Bulgarian coast has been attributed to removal of evidence by sea-level rise (Gurova and Bonsall 2014). Given the emphasis on hunting, fowling and marine exploitation even in the Eneolithic and EBA periods, and the importance of forest clearings along the edges of coastlines, rivers and 
lakes, it is likely that coastal lowlands would have been just as attractive to earlier agricultural and pre-agricultural populations and just as capable of supporting large settlements. The challenge will be to find these earlier sites, particularly if they are deeply buried beneath later marine deposits.

New work is now under way, including the use of predictive modelling and remote sensing in shallow water (Prahov 2013), and underwater excavation in shallow water and geophysical prospection and coring in deeper water offshore by BSMAP. Without such investigations, the nature of the relationship between the underwater Eneolithic and Early Bronze Age settlements and changes in sea level will remain unclear, while questions about the nature of earlier human settlement on the more deeply submerged landscapes of the Black Sea shelf, and the likely impact of more or less rapid sea-level rise in the Late Glacial and Early Postglacial, will remain largely in the realms of speculation.

\subsection{Conclusion: Issues of Future Research and Management}

The submerged prehistoric settlements of the Bulgarian coast, though relatively late in date, provide a unique insight into the social and economic history of the period and a unique archive of data with which to investigate the interactions between social development and changes in the natural environment. Even in these relatively shallow and accessible waters, there remain large challenges. Only a small fraction of the known underwater settlements has been systematically investigated, and much of the material recovered in earlier excavations has untapped potential for further analysis and renewed underwater investigations of the locations which have previously yielded archaeological discoveries. At the same time, the coastal zone is increasingly an area of intensive commercial and industrial development and economic activity, especially in more shallow, inshore waters. Fishing, gathering of Rapana (a large gastropod), hydrocarbon exploration, installation of oil and gas pipelines and underwater cables and the dredging of ports and shipping channels, all have the potential to damage or destroy the submerged cultural heritage. Bulgaria is exemplary in its systematic management of archaeology and coordination of protection with research, conservation and collaboration across a wide range of disciplines and institutions at a national and an international level. Bulgaria is a party to the UNESCO 2001 Convention on the Protection of the Underwater Cultural Heritage. The competent state authority responsible for the protection of the underwater cultural heritage is the Centre for Underwater Archaeology, Sozopol, which falls under the jurisdiction of the Ministry of Culture (UNESCO 2010b) and is responsible for investigation, recording, protection, consultancy, public outreach and training. What is now required are the resources on a scale to match the demands of this new and challenging agenda.

Acknowledgements We thank the following for their support of the research reported here: HERAS Project (Submarine Archaeological Heritage on the Western Black Sea Shelf - HERAS), CBC Program RomaniaBulgaria 2007-2013, the Black Sea Maritime Archaeology Project (BSMAP) supported by the Julia and Hans Rausing Trust, the Centre for Underwater Archaeology Sozopol, the University of Southampton, and the EU through COST Action TD 0902 SPLASHCOS. We also thank John Chapman and Bisserka Gaydarska for provision of information, critical comments on the text and helpful discussion of chronology, and Kurt Lambeck and Dimitris Sakellariou for information on sea-levels. Author contributions: PP, RHF, VS: fieldwork, research, analysis, writing; MJG, JA: fieldwork, research; and GB: research, analysis, writing.

\section{References}

Aksu AE, Hiscott RN, Kaminski MA, Mudie PJ, Gillespie H, Abrajano T, Yaşar D (2002) Late Glacial-Holocene palaeoceanography of the Black Sea and Marmara shelf: Stable isotopic, foraminiferal and coccolithic evidence. Marine Geol 190:119-149

Alekseev M, Chistyakov A, Shterbakov F (1986) Chetvertichnaya Geologiya Materikovyih Okrain. Nedra, Moscow (in Russian)

Angelova H, Draganov V (2003) Underwater archaeological excavations of submerged Late Eneolithic and Early Bronze Age settlements in Kiten and Sozopol (South Bulgarian Black Sea coast). In: Angelova H (ed) In Honorem Mihaili Lazarov. Thracia Pontica 6.2:9-22 
Badertscher S, Fleitmann D, Cheng H, Edwards RL, Göktürk OM, Zumbühl A, Leuenberger M, Tüysüz O (2011) Pleistocene water intrusions from the Mediterranean and Caspian seas into the Black Sea. Nat Geosci 4:236-239

Balabanov IP (2007) Holocene sea-level changes of the Black Sea. In: Yanko-Hombach V, Gilbert A, Panin N, Dolukhanov P (eds) The Black Sea flood question: Changes in coastline, climate, and human settlement. Springer, Dordrecht, pp 711-730

Ballard RD, Hiebert FT, Coleman DF, Ward C, Smith JS, Willis K, Foley B, Croff K, Major C, Torre F (2001) Deepwater archaeology of the Black Sea: the 2000 season at Sinop, Turkey. Am J Archaeol 105:607-623

Boyadziev YD (1995) Chronology of prehistoric cultures in Bulgaria. In: Bailey D, Panayotov I (eds) Prehistoric Bulgaria. Prehistory Press, Madison, pp 149-191

Caraivan G, Voinea V, Popescu D, Cerchi C (2017) Submerged prehistoric potential of the Romanian Black Sea shelf. In: Flemming NC, Harff J, Moura D, Burgess A, Bailey GN (eds) Submerged landscapes of the European continental shelf: quaternary paleoenvironments. Wiley, Chichester, pp 497-517

Chapman J (1989) Demographic trends in Neothermal South-east Europe. In: Bonsall C (ed) The Mesolithic in Europe. John Donald, Edinburgh, pp 500-515

Constantinescu AM, Toucanne S, Dennielou B, Jorry SJ, Mulder T, Lericolais G (2015) Evolution of the Danube deep-sea fan since the last glacial maximum: new insights into Black Sea water-level fluctuations. Mar Geol 367:50-68

Dachev V (2003) Genesis and evolution of Varna Central Beach. Proc Inst Oceanol 4:74-82 (in Bulgarian)

Draganov V (1995) Submerged coastal settlements from the Final Eneolithic and the Early Bronze Age in the sea around Sozopol and Urdoviza Bay near Kiten. In: Bailey D, Panayotov I (eds) Prehistoric Bulgaria. Prehistory Press, Madison, pp 225-241

Draganov V (1998) James Harvey Gaul and the present state of Eneolithic research in northeastern Bulgaria and Thrace: the areas of the Krivodol-GumelnitaKaranovo VI and Varna cultures. In: Stefanovich M, Todorova H, Hauptmann H (eds) In the steps of James Harvey Gaul, James Harvey Gaul - in memoriam, vol 1. The James Harvey Gaul Foundation, Sofia, pp 203-221

Filipova-Marinova M (2007) Archaeological and paleontological evidence of climate dynamics, sea-level change, and coastline migration of the Bulgarian sector of the Circum-Pontic region. In: YankoHombach V, Gilbert A, Panin N, Dolukhanov P (eds) The Black Sea flood question: changes in coastline, climate, and human settlement. Springer, Dordrecht, pp 453-482

Filipova-Marinova M, Liviu G, Angelova H, Preisinger A, Pavlov D, Vergiev S (2011) Palaeoecology of submerged prehistoric settlements in Sozopol harbour, Bulgaria. In: Benjamin J, Bonsall C, Pickard C, Fischer A (eds) Submerged prehistory. Oxbow, Oxford, pp 230-244
Filipova-Marinova M, Pavlov D, Giosan L (2016) Multi-proxy records of Holocene palaeoenvironmental changes in the Varna Lake area, western Black Sea coast. Quater Int 401:99-108. https://doi. org/10.1016/j.quaint.2015.05.009

Giosan L, Filip F, Constatinescu S (2009) Was the Black Sea catastrophically flooded in the early Holocene? Quater Sci Rev 28:1-6. https://doi.org/10.1016/j. quascirev.2008.10.012

Glebov AY, Shel'ting SK (2007) Sea-level changes and coastline migrations in the Russian sector of the Black Sea: application to the Noah's Flood hypothesis. In: Yanko-Hombach V, Gilbert A, Panin N, Dolukhanov $\mathrm{P}$ (eds) The Black Sea flood question: changes in coastline, climate, and human settlement. Springer, Dordrecht, pp 731-773

Gurova M, Bonsall C (2014) 'Pre-Neolithic' South East Europe: a Bulgarian perspective. Documenta Praehistoria 41:95-109

Higham T, Chapman J, Slavchev V, Gaydarska B, Honch N, Yordanov Y, Dimitrova B (2007) New perspectives on the Varna cemetery (Bulgaria)-AMS dates and social implications. Antiquity 81:640-654

Hiscott RN, Aksu AE, Mudie PJ, Marret F, Abrajano T, Kaminski MA, Evans J, Çakiroğlu AI, Yaşarf D (2007) A gradual drowning of the southwestern Black Sea shelf: Evidence for a progressive rather than abrupt Holocene reconnection with the eastern Mediterranean Sea through the Marmara Sea Gateway. Quater Int 167-168:19-34. https://doi.org/10.1016/j. quaint.2006.11.007

Ivanov I (1987) Podvodni arheologicheski prouchvania na selishte Arsenala. Arheologicheski otkritiya i razkopki prez 1986. Razgrad, 281-283 (in Bulgarian)

Ivanov I (1993) A la question de la localisation et des études des sites submergés dans les lacs de Varna. Pontica 26:19-26

Ivanov VA, Belokopytov VN (2013) Oceanography of the Black Sea. Hydrophysical Institute NAS of Ukraine, Sevastopol

Ivanova M (2013) The Black Sea and the early civilizations of Europe, the Near East and Asia. Cambridge University Press, Cambridge. https://doi.org/10.1017/ CBO9781139424738

Kalafat D (2017) Seismicity and tectonics of the Black Sea. Int J Earth Sci Geophy 3:011. https://www.vibgyorpublishers.org/content/international-journal-ofearth-science-and-geophysics/ijesg-3-011.pdf

Karayotov I (1990) The Antique and Medieval port at the mouth of the river Ropotamo. Acta TAB 5:64-66

Kislov A (2018) On the interpretation of centurymillennium-scale variations of the Black Sea level during the first quarter of the Holocene. Quater Int 465(A):99-104. https://doi.org/10.1016/j. quaint.2016.09.008

Kotsev I, Stanchev H, Stancheva M, Filipova-Marinova M, Yankova M, Peev P, Peychev V, Krastev A, Palazov A, Pavlov D (2017) Sensitivity mapping and analysis of the Bulgarian Black Sea coastal zone. Total E\&P Bulgaria B.V, Sofia 
Kuniholm PI, Kromer B, Tarter SL, Griggds CB (1998) An Early Bronze Age settlement at Sozopol, near Burgas, Bulgaria., dated by dendrochronology and radiocarbon. In: Stefanovich M, Todorova H, Hauptmann $\mathrm{H}$ (eds) In the steps of James Harvey Gaul, Volume 1: James Harvey Gaul - in memoriam. The James Harvey Gaul Foundation, Sofia, pp 399-409

Kuniholm PI, Newton MW, Kromer B (2007) Dendrochronology of submerged Bulgarian sites. In: Yanko-Hombach V, Gilbert A, Panin N, Dolukhanov $\mathrm{P}$ (eds) The Black Sea flood question: changes in coastline, climate, and human settlement. Springer, Dordrecht, pp 483-488

Lambeck K, Purcell A (2005) Sea-level change in the Mediterranean Sea since the LGM: model predictions for tectonically stable areas. Quater Sci Rev 24(18-19):1969-1988

Lambeck J, Sivan D, Purcell A (2007) Timing of the last Mediterranean Sea-Black Sea connection from isostatic models and regional sea-level data. In: YankoHombach V, Gilbert A, Panin N, Dolukhanov P (eds) The Black Sea flood question: changes in coastline, climate, and human settlement. Springer, Dordrecht, pp 797-808

Lazarov M (1996) Sunken settlements along the Western Black Sea in the context of Pontic and Eastern Mediterranean history. History 1:48-61 (in Bulgarian)

Lericolais G (2017) Late Pleistocene environmental factors defining the Black Sea, and submerged landscapes on the western continental shelf. In: Flemming NC, Harff J, Moura D, Burgess A, Bailey GN (eds) Submerged landscapes of the European continental shelf: quaternary paleoenvironments. Wiley, Chichester, pp 479-495

Lericolais G, Guichard F, Morigi C, Popescu I, Bulois C, Gillet H, Ryan WBF (2011) Assessment of the Black Sea water-level fluctuations since the Last Glacial Maximum. In: Buynevich IV, Yanko-Hombach V, Gilbert AS, Martin RE (eds) Geology and geoarchaeology of the Black Sea region: beyond the Flood Hypothesis, Geological Society of America Special Paper 473, pp 33-50

Margos A (1972) Mikroliti ot eneolitni selishta vuv Varnensko. Izvestiya na Narodniya Muzei Varna 8(23):233-235 (in Bulgarian)

Meriç E, Nazik A, Yümün ZU, Büyükmeriç Y, Avşar N, Yildiz A, Sagular EK, Koral H, Gökaşan E (2018) Fauna and flora of drilling and core data from the İnik Lake: The Marmara and the Black Sea connection. Quater Int 486:156-184

Mgeladze A, Lordkipanidze D, Moncel MH, Despriee J, Chagelishvili R, Nioradze M, Nioradze G (2011) Hominin occupations at the Dmanisi site, Georgia, Southern Caucasus: Raw materials and technical behaviours of Europe's first hominins. J Human Evol 60:571-596. https://doi.org/10.1016/j. jhevol.2010.10.008

Nicholas WA, Chivas AR, Murray-Wallace CV, Fink D (2011) Prompt transgression and gradual salinisation of the Black Sea during the early Holocene con- strained by amino acid racemization and radiocarbon dating. Quater Sci Rev 30(27-28):3769-3790

Nikishin AM, Korotaev MV, Eshov AV, Brunet M-F (2003) The Black Sea basin: Tectonic history and Neogene-Quaternary rapid subsidence modelling. Sediment Geol 156:149-168

Nikolova L (1994) Data about sea contacts during the Early Bronze Age in South-Eastern Europe (C. 3500/3400 2350/2250 B.C.). Thracia Pontica 5:57-86

Orachev A (1990) Contributions to the paleogeography of the coast of Dobroudja. Dobrudzha 7:35-52 (In Bulgarian)

Özdoğan M (2011) Submerged sites and drowned topographies along the Anatolian coasts: an overview. In: Benjamin J, Bonsall C, Pickard C, Fischer A (eds) Submerged prehistory. Oxbow, Oxford, pp 219-229

Peev P (2008a) Underwater sites in the area of cape Shabla (North-East Bulgaria). In: Kostov R, Gaydarska B, Gurova M (eds) Geoarchaeology and Archaeomineralogy. Proceedings of the International Conference 29-30 October - Sofia. St. Ivan Rilski, Sofia, pp 303-304

Peev P (2008b) Physico-geographical description of the Varna bay. In: Varna in the middle ages. Part 1. From the 7th to 10th Century. Zograf, Varna, pp 250-280 (in Bulgarian)

Peev P (2009) The Neolithisation of the Eastern Balkan Peninsula and fluctuations of the Black Sea level. Quater Int 197:87-92. https://doi.org/10.1016/j. quaint.2008.04.019

Peev P, Slavchev V (2018) Bulgaria - burials and wooden settlement structures. In: Fischer A, Pedersen L (eds) Oceans of archaeology. Jutland Archaeological Society and Aarhus University Press, Aarhus, pp 94-99

Peychev V, Peev P (2006) Evolyutzia na bulgarskoto chernomorsko kraibrezhie sled rannia holotzen. Slavena, Varna (in Bulgarian)

Pirazzoli PA (1996) Sea-Level changes: the last 20,000 years. Wiley, Chichester

Popov V, Mishev K (1974) Geomorphology of the Bulgarian Black Sea coast and shelf. BAS, Sofia (in Bulgarian)

Porozhanov K (1991) Le site submergé d'Ourdoviza. Thracia Pontica 4:109-112

Porozhanov K (2004) The Early Bronze Age sunken settlement by Urdoviza (1986-1988 Archaeological Campaigns). In: Slavchev V (ed) Studies in honour of Prof. Dr.hist.Sc. Henrietta Todorova. Dobrudzha 21 (2003), pp 309-322 (in Bulgarian with English Summary)

Prahov N (2013) Archaeological predictive model for late Chalcolithic and Early Bronze Age coastal settlements along the southern Bulgarian sea coast. In: Angelova H, Özdoğan M (eds) International Conference. Where are the sites? Research, protection and management of cultural heritage, 5-8 December 2013, Ahtopol. Organised by Centre for Underwater Archaeology, Sozopol, Bulgaria, pp 117-146

Ryan WBF (2007) Status of the Black Sea flood hypothesis. In: Yanko-Hombach V, Gilbert A, Panin N, 
Dolukhanov P (eds) The Black Sea Flood Question: changes in coastline, climate, and human settlement. Springer, Dordrecht, pp 63-88

Ryan WBF, Pitman WC, Major CO, Shimkus K, Moskalenko V, Jones GA, Dimitrov P, Gorür N, Sakinç M, Yüce H (1997) An abrupt drowning of the Black Sea shelf. Mar Geol 138:119-126. https://doi. org/10.1016/S0025-3227(97)00007-8

Ryan WBF, Major CO, Lericolais G, Goldstein SL (2003) Catastrophic flooding of the Black Sea. Ann Rev Earth Planet Sci 31:525-554

Shkorpil H, Shkorpil K (1921) Nakolni postroiki v ezeroto. Izvestiya na Varnenskoto Arheologichesko Druzhestvo 7:79-80 (in Bulgarian)

Sorokin VM, Kuprin PN (2007) On the character of Black Sea level rise during the Holocene. Moscow Univ Geol Bull 62:334-341. https://doi.org/10.3103/ S0145875207050055

Soulet G, Ménot G, Garreta V, Rostek F, Zaragosi S, Lericolais G, Bard E (2011) Black Sea "Lake" reservoir age evolution since the Last Glacial Hydrologic and climatic implications. Earth Planet Sci Lett 308(1-2):245-258. https://doi.org/10.1016/j. epsl.2011.06.002

Soulet G, Ménot G, Bayon G, Rostek F, Ponzevera E, Toucanne S, Lericolais G, Bard E (2013) Abrupt drainage cycles of the Fennoscandian Ice Sheet. Proc Nat Acad Sci USA 110(17):6682-6687 www.pnas. org/cgi/doi/10.1073/pnas. 1214676110

Spassov N, Iliev N (1994) Animal remains from the submerged Late Eneolithic - Early Bronze Age settlements in Sozopol (south Bulgarian Black Sea coast). Proc Int Symp Thracia Pontica VI 18-24 September 1994, pp 287-314

Stanchev H, Young R, Stancheva M (2013) Integrating GIS and high-resolution orthophoto images for the development of a geomorphic shoreline classification and risk assessment - a case study of cliff/bluff erosion along the Bulgarian coast. J Coast Conserv 17:719728. https://doi.org/10.1007/s11852-013-0271-2

Stancheva M (2013) Bulgaria. In: Pranzini E, Williams A (eds) Coastal erosion and protection in Europe. Routledge, Abingdon, pp 378-395

Stanimirov S (2003) The western Black Sea coast in the Eneolithic and Bronze Ages. Athena Rev 3(4) http:// www.athenapub.com/AR/12blksea.htm

Stephenson R, Schellart WP (2010) The Black Sea back-arc basin: Insights to its origin from geodynamic models of modern analogues. Geol Soc London Spec Publications 340:11-12. https://doi.org/10.1144/SP340.2

Sturt F, Flemming NC, Carabias D, Jöns H, Adams J (2018) The next frontiers in research on submerged prehistoric sites and landscapes on the continental shelf. Proceedings of the Geologists' Association (2018). doi:https://doi.org/10.1016/j.pgeola.2018.04.008

Todorova H (1978) Prouchvania na neolita I eneolita v Longoza (nachaloto na VI-kraya na V hilyadoletie pr.n.e.). Izvestiya na Narodniya Muzei Varna 14(29):1-9 (in Bulgarian)
Todorova H (1984) Dobrudzha during Prehistoric Age. In: Fol A, Dimitrov S (eds) History of Dobrudzha Tome 1. BAS, Sofia, pp 23-71 (in Bulgarian)

Todorova H (1995) The Neolithic, Eneolithic and Transitional period in Bulgarian prehistory. In: Bailey D, Panayotov I (eds) Prehistoric Bulgaria. Prehistory Press, Madison, pp 79-98

Turney CSM, Brown H (2007) Catastrophic early Holocene sea level rise, human migration and the Neolithic transition in Europe. Quater Sci Rev 26:2036-2041. https://doi.org/10.1016/j.quascirev.2007.07.003

UNESCO (2010a) Romania: National Report on underwater cultural heritage: Report made in the UNESCO Regional Meeting in Istanbul 25-27 October, 2010. http://unesdoc.unesco.org/ images/0018/001899/189966E.pdf

UNESCO (2010b) Bulgaria: National Report on underwater cultural heritage: Report made in the UNESCO Regional Meeting in Istanbul 25-27 October, 2010. http://unesdoc.unesco.org/ images/0018/001899/189942E.pdf

Velkovsky K, Angelova H, Dragonov V, Prahov N, Dragomir G, Orachev A, Petrov P (2013) Geophysical prospecting and underwater archaeology. Bathymetric and sidescan sonar surveys in the aquatoria of Sozopol-Sinemorets, 2013. In: Angelova H, Özdoğan M (eds) International Conference. Where are the sites? Research, protection and management of cultural heritage, 5-8 December 2013, Ahtopol. Organised by Centre for Underwater Archaeology, Sozopol, Bulgaria, pp 147-154

Yanchilina AG, Ryan WBF, McManus JF, Dimitrov P, Dimitrov D, Slavova K, Filipova-Marinova M (2017) Compilation of geophysical, geochronological, and geochemical evidence indicates a rapid Mediterranean-derived submergence of the Black Sea's shelf and subsequent substantial salinification in the early Holocene. Mar Geol 383:14-34. https://doi. org/10.1016/j.margeo.2016.11.001

Yanko-Hombach V (2007) Controversy over Noah's Flood in the Black Sea: Geological and foraminiferal evidence from the shelf. In: Yanko-Hombach V, Gilbert A, Panin N, Dolukhanov P (eds) The Black Sea flood question: changes in coastline, climate, and human settlement. Springer, Dordrecht, pp 149-203. https://doi.org/10.1007/978-1-4020-5302-3_7

Yanko-Hombach V, Gilbert AS, Dolukhanov P (2007a) Controversy over the great flood hypotheses in the Black Sea in light of geological, paleontological, and archaeological evidence. Quater Int 167:91-113. https://doi.org/10.1016/j.quaint.2006.08.004

Yanko-Hombach V, Gilbert A, Panin N, Dolukhanov P (eds) (2007b) The Black Sea Flood Question: changes in coastline, climate, and human settlement. Springer, Dordrecht

Yanko-Hombach V, Mudie P, Gilbert AS (2011) Was the Black Sea catastrophically flooded during the postglacial? Geological evidence and archaeological impacts. In: Benjamin J, Bonsall C, Pickard C, Fischer 
A (eds) Submerged prehistory. Oxbow, Oxford, pp 45-262

Yanko-Hombach V, Mudie PJ, Kadurin S, Larchenkov E (2014) Holocene marine transgression in the Black Sea: New evidence from the Northwestern Black Sea shelf. Quater Int 345:100-118

Yanko-Hombach V, Schnyukov E, Pasynkov A, Sorokin V, Kuprin P, Maslakov N, Motnenko I, Smyntyna O (2017) Late Pleistocene-Holocene environmental factors defining the Azov-Black Sea basin, and the identification of potential sample areas for seabed prehistoric site prospecting and landscape exploration on the Black Sea continental shelf. In: Flemming NC, Harff J, Moura D, Burgess A, Bailey GN (eds) Submerged landscapes of the European continental shelf: quaternary paleoenvironments. Wiley, Chichester, pp 431-478

Open Access This chapter is licensed under the terms of the Creative Commons Attribution 4.0 International License (http://creativecommons.org/licenses/by/4.0/), which permits use, sharing, adaptation, distribution and reproduction in any medium or format, as long as you give appropriate credit to the original author(s) and the source, provide a link to the Creative Commons licence and indicate if changes were made.

The images or other third party material in this chapter are included in the chapter's Creative Commons licence, unless indicated otherwise in a credit line to the material. If material is not included in the chapter's Creative Commons licence and your intended use is not permitted by statutory regulation or exceeds the permitted use, you will need to obtain permission directly from the copyright holder. 